\title{
DRYING KINETICS OF BARU FRUITS (Dipteryx alata Vogel)
}

\section{Osvaldo Resende ${ }^{1 *}$, Daniel E. C. de Oliveira ${ }^{2}$, Lílian M. Costa ${ }^{3}$, Weder N. Ferreira Júnior ${ }^{3}$}

\author{
${ }^{1 *}$ Corresponding author. Instituto Federal de Educação, Ciência e Tecnologia Goiano - Campus Rio Verde/ Rio Verde - GO, \\ Brasil. E-mail: osvaldo.resende@ifgoiano.edu.br
}

\section{KEYWORDS}

mathematical modeling, liquid diffusivity, logarithmic.

\begin{abstract}
This study aimed to fit different mathematical models to the experimental data on drying of baru fruits (Dipteryx alata Vogel), determine and assess the effective diffusion coefficient, as well as obtain the activation energy and thermodynamic properties for the drying process under different air temperature conditions. Baru fruits with an initial moisture content of $0.429 \pm 0.044$ (dry basis, $\mathrm{db}$ ) were dried in a forced air ventilation oven under four temperature conditions $\left(40,60,80\right.$, and $\left.100{ }^{\circ} \mathrm{C}\right)$ until reaching a moisture content of $0.065 \pm 0.018$ (decimal db). These data were fitted to mathematical models frequently used to represent the drying of vegetal products. The Logarithmic model presented the best fit to describe the phenomenon. The effective diffusion coefficient increased as temperature increased, being described by the Arrhenius equation, with an activation energy of $37.64 \mathrm{~kJ} \mathrm{~mol}^{-1}$. Enthalpy and entropy decreased, while Gibbs free energy increased as drying temperature increased.
\end{abstract}

\section{INTRODUCTION}

Baru (Dipteryx alata Vogel) belongs to the Fabaceae family, occurring in the most fertile soils of Cerrado. This tree species can reach more than 15 meters in height and presents an erect stem and smooth branches (Correa et al., 2008). Its fruits have pulp and almonds used for human consumption.

Among the post-harvest processes used to maintain the quality of agricultural products, drying stands out as a way of reducing biological activity and minimizing losses in fruit quality during storage. Conditions and methods adopted for drying should be adjusted to the characteristics of each agricultural product (Silva et al., 2015). Thus, obtaining theoretical information on drying of baru fruits is relevant.

Drying is an essential process in the technology used for the production of high-quality fruits as it allows reducing the moisture content at adequate levels of storage, preserving their physical and chemical characteristics. Thus, it is possible to maintain a good quality of fruits (pulp and almonds) during storage, allowing harvests close to the physiological maturity.

The study of drying process provides information on the characteristics of energy and mass transfer between fruit and air. In this sense, numerous studies have been developed aiming at identifying the characteristics of several agricultural products during drying such as crambe fruits (Costa et al., 2015), jagua leaves (Silva et al., 2015), bonnet pepper (Rodovalho et al., 2015), and 'Cabacinha' pepper fruits (Silva et al., 2016).

Considering the importance of the theoretical study of drying process of plant products, this study aimed to fit different mathematical models to the experimental data of on drying of baru fruits, determine and assess the effective diffusion coefficient, as well as obtain the activation energy and thermodynamic properties for this process during drying under different air conditions.

\section{MATERIAL AND METHODS}

The experiment was carried out at the Laboratory of Post-Harvest of Plant Products of the Federal Institute of Education, Science, and Technology of Goiás, campus of Rio Verde, GO, Brazil. Fruits of baru (D. alata Vogel) were manually collected in Santa Helena de Goiás (GO) and presented an initial moisture content of $0.429 \pm 0.044$ dry basis (decimal, dry basis, db).

These fruits were submitted to a forced air ventilation oven under four temperature conditions (40, 60, 80 , and $100{ }^{\circ} \mathrm{C}$ ), which promoted average relative moistures of $25.1,12.2,5.3$, and $1.7 \%$, respectively. For conducting the experiment, moisture contents were obtained by forced-air drying with an airflow of $0.3313 \mathrm{~m}^{3}$

\footnotetext{
${ }^{2}$ Instituto Federal de Educação, Ciência e Tecnologia Goiano - Campus Iporá/ Iporá - GO, Brasil.

${ }^{3}$ Instituto Federal de Educação, Ciência e Tecnologia Goiano - Campus Rio Verde/ Rio Verde - GO, Brasil.

Received in: 8-2-2016
}

Accepted in: 10-30-2017 
$\mathrm{s}^{-1}$. Drying continued until the fruits reached a moisture content of $0.065 \pm 0.018$ (decimal db), determined in an oven at $105 \pm 3{ }^{\circ} \mathrm{C}$ for $24 \mathrm{~h}$ (Brasil, 2009).

The experimental design was a completely randomized design with three replications in $1 \mathrm{~kg}$ portions per drying temperature with a layer height of approximately $5 \mathrm{~cm}$. The reduction in moisture content during drying process was estimated by the gravimetric method (loss of mass), starting from the initial moisture content, considering the reduction in fruit mass measured with a $0.01 \mathrm{~g}$ precision scale. Weighings were initially performed every 15 minutes and, subsequently, these periods were progressively increased.

Drying air temperature and the relative humidity and ambient temperature were monitored by means of a thermohygrometer located inside and outside the dryer. The relative humidity inside the oven was obtained by means of basic principles of psychrometry by using the software GRAPSI.

Moisture content ratios of baru fruits during drying were determined as the following expression:

$$
\mathrm{RX}=\frac{\mathrm{X}-\mathrm{X}_{\mathrm{e}}}{\mathrm{X}_{\mathrm{i}}-\mathrm{X}_{\mathrm{e}}}
$$

where,

$\mathrm{RX}$ is the moisture content ratio of the product (dimensionless);

$\mathrm{X}$ it the moisture content in the product $(\mathrm{db})$;

$\mathrm{X}_{\mathrm{i}}$ is the initial moisture content in the product $(\mathrm{db})$, and

$\mathrm{X}_{\mathrm{e}}$ is the equilibrium moisture content in the product $(\mathrm{db})$.

To obtain the equilibrium moisture content of baru fruits at each drying temperature, the modified Halsey model was used, as indicated by [eq. (2)].

$$
\mathrm{X}_{\mathrm{e}}=\left[\exp \left(2.8707^{* *}-0.0084^{* *} \cdot \mathrm{T}\right) /-\ln \left(\mathrm{a}_{\mathrm{w}}\right)\right]^{\frac{1}{1.2483^{* *}}}
$$

where,

${ }^{* *}$ is significant at $1 \%$ by the t-test.

Mathematical models frequently used to represent the drying of plant products (Table 1) were fitted to the experimental data of drying of baru fruits.

\begin{tabular}{|c|c|c|}
\hline Model designation & Model & \\
\hline $\mathrm{RX}=1+\mathrm{at}+\mathrm{bt}^{2}$ & Wang and Sing & (3) \\
\hline $\mathrm{RX}=\mathrm{a} \cdot \exp (-\mathrm{k} \cdot \mathrm{t})+(1-\mathrm{a}) \exp \left(-\mathrm{k}_{1} \cdot \mathrm{t}\right)$ & Verma & (4) \\
\hline $\mathrm{RX}=\exp \left(\left(-\mathrm{a}-\left(\mathrm{a}^{2}+4 \cdot \mathrm{b} \cdot \mathrm{t}\right)^{0,5}\right) / 2 \cdot \mathrm{b}\right)$ & Thompson & (5) \\
\hline $\mathrm{RX}=\exp \left(-\mathrm{k} \cdot \mathrm{t}^{\mathrm{n}}\right)$ & Page & (6) \\
\hline $\mathrm{RX}=\exp (-\mathrm{k} \cdot \mathrm{t})$ & Newton & (7) \\
\hline $\mathrm{RX}=\mathrm{a} \cdot \exp \left(-\mathrm{k} \cdot \mathrm{t}^{\mathrm{n}}\right)+\mathrm{b} \cdot \mathrm{t}$ & Midilli & (8) \\
\hline $\mathrm{RX}=\mathrm{a} \cdot \exp (-\mathrm{k} \cdot \mathrm{t})+\mathrm{c}$ & Logarithmic & (9) \\
\hline $\mathrm{RX}=\mathrm{a} \cdot \exp (-\mathrm{k} \cdot \mathrm{t})$ & Henderson and Pabis & $(10)$ \\
\hline $\mathrm{RX}=\mathrm{a} \cdot \exp (-\mathrm{k} \cdot \mathrm{t})+(1-\mathrm{a}) \exp (-\mathrm{k} \cdot \mathrm{a} \cdot \mathrm{t})$ & Exponential of two terms & (11) \\
\hline $\mathrm{RX}=\mathrm{a} \cdot \exp \left(-\mathrm{k}_{\mathrm{O}} \cdot \mathrm{t}\right)+\mathrm{b} \cdot \exp \left(-\mathrm{k}_{1} \cdot \mathrm{t}\right)$ & Two terms & $(12)$ \\
\hline$R X=a \cdot \exp (-k \cdot t)+(1-a) \cdot \exp (-k \cdot b \cdot t)$ & Diffusion approximation & $(13)$ \\
\hline
\end{tabular}

TABLE 1. Mathematical models used to predict the drying of plant products.

$\mathrm{t}$ : drying time; $\mathrm{h} ; \mathrm{k}, \mathrm{k}_{\mathrm{o}}$, and $\mathrm{k}_{1}$ : drying constants $\left(\mathrm{h}^{-1}\right)$; and $a, b, c$, and $\mathrm{n}$ : model parameters.

Mathematical models were fitted by means of nonlinear regression analysis using the Gauss-Newton method and, for the degree of fit, the magnitudes of the coefficient of determination $\left(\mathrm{R}^{2}\right)$, chi-square test $\left(\chi^{2}\right)$, mean relative error $(\mathrm{P})$, and the estimated mean error (SE) were considered as follows:

$$
\mathrm{P}=\frac{100}{\mathrm{n}} \sum \frac{|\mathrm{Y}-\hat{\mathrm{Y}}|}{\mathrm{Y}}
$$

$$
\begin{aligned}
& \mathrm{SE}=\sqrt{\frac{\sum(\mathrm{Y}-\hat{\mathrm{Y}})^{2}}{\mathrm{DF}}} \\
& \chi^{2}=\sum \frac{(\mathrm{Y}-\hat{\mathrm{Y}})^{2}}{\mathrm{DF}}
\end{aligned}
$$

where,

$\mathrm{Y}$ is the experimental value; 
$\hat{\mathrm{Y}}$ is the value estimated by the model;

$\mathrm{n}$ is the number of experimental observations, and

$\mathrm{DF}$ is the degree of freedom of the model (number of observations minus the number of model parameters).

Net diffusion was described by the geometric shape model of an infinite cylinder with an approximation of eight terms, according to the following expression:

$$
\mathrm{RX}=\frac{\mathrm{X}-\mathrm{X}_{\mathrm{e}}}{\mathrm{X}_{\mathrm{i}}-\mathrm{X}_{\mathrm{e}}}=\sum_{\mathrm{n}_{\mathrm{t}}=1}^{\infty} \frac{4}{\lambda_{\mathrm{n}}^{2}} \exp \left[-\frac{\lambda_{\mathrm{n}}^{2} \cdot \mathrm{D} \cdot \mathrm{t}}{4} \cdot\left(\frac{2}{\mathrm{r}}\right)^{2}\right]
$$

where,

$\mathrm{n}_{\mathrm{t}}$ is the number of terms;

$\mathrm{D}$ is the net diffusion coefficient $\left(\mathrm{m}^{2} \mathrm{~s}^{-1}\right)$;

$r$ is the equivalent radius ( $m$ ), and

$\lambda_{n}$ is the roots of the zero-order Bessel equation.

The fruit equivalent radius was determined by the following expression:

$$
r=\sqrt[3]{\frac{3 \cdot V_{f}}{4 \cdot \pi}}
$$

where,

$$
\mathrm{V}_{\mathrm{f}} \text { it the fruit volume }\left(\mathrm{m}^{-3}\right) \text {. }
$$

Fruit volume $\left(\mathrm{V}_{\mathrm{f}}\right)$ was obtained by measuring the three orthogonal axes (length, width, and thickness) in fifteen fruits at the end of drying process using a digital caliper with a precision of $0.01 \mathrm{~mm}$ and calculated according to the following expression:

$$
\mathrm{V}_{\mathrm{f}}=\frac{\pi \cdot \mathrm{A} \cdot \mathrm{B} \cdot \mathrm{C}}{6}
$$

where,

A is the length (m);

$B$ is the width (m), and

$\mathrm{C}$ is the thickness (m).

The relationship between the effective diffusion coefficient and the rising of the drying air temperature was described by the Arrhenius equation.

$$
\mathrm{D}=\mathrm{D}_{\mathrm{o}} \cdot \exp \left(\frac{-\mathrm{E}_{\mathrm{a}}}{\mathrm{R} \cdot \mathrm{T}_{\mathrm{abs}}}\right)
$$

where,

$D_{0}$ is the pre-exponential factor,

$\mathrm{E}_{\mathrm{a}}$ is the activation energy $\left(\mathrm{kJ} \mathrm{mol}^{-1}\right)$,

$\mathrm{R}$ is the universal gas constant $\left(8.134 \mathrm{~kJ} \mathrm{kmol}^{-1} \mathrm{~K}^{-1}\right)$, and

$\mathrm{T}_{\mathrm{abs}}$ is the absolute temperature $(\mathrm{K})$.

The thermodynamic properties of the drying process of baru fruit were obtained by the method described by Jideani \& Mpotokwana (2009):

$$
\begin{aligned}
& \mathrm{H}=\mathrm{E}_{\mathrm{a}}-\mathrm{R} \cdot \mathrm{T} \\
& \mathrm{S}=\mathrm{R} \cdot\left(\ln \mathrm{k}-\ln \frac{\mathrm{k}_{\mathrm{B}}}{\mathrm{h}_{\mathrm{p}}}\right)-\ln \mathrm{T}_{\mathrm{abs}} \\
& \mathrm{G}=\mathrm{H}-\mathrm{T}_{\mathrm{abs}} \cdot \mathrm{S}
\end{aligned}
$$

where,

$$
\begin{aligned}
& \mathrm{H} \text { is the enthalpy }\left(\mathrm{J} \mathrm{mol}^{-1}\right) \text {; } \\
& \mathrm{S} \text { is the entropy }\left(\mathrm{J} \mathrm{mol}^{-1}\right) \text {; } \\
& \mathrm{G} \text { is the Gibbs free energy }\left(\mathrm{J} \mathrm{mol}^{-1}\right) \text {; } \\
& \mathrm{k}_{\mathrm{B}} \text { is the Boltzmann's constant }\left(1.38 \times 10^{-23} \mathrm{~J} \mathrm{~K}^{-1}\right) \text {, and } \\
& \mathrm{h}_{\mathrm{p}} \text { is the Planck's constant }\left(6.626 \times 10^{-34} \mathrm{~J} \mathrm{~s}^{-1}\right) \text {. }
\end{aligned}
$$

\section{RESULTS AND DISCUSSION}

The time required for the fruits to reach a moisture content of $0.065 \pm 0.018(\mathrm{db})$ was $266.3,166.9,30.8$, and $22.8 \mathrm{~h}$ for the drying temperatures $40,60,80$, and $100{ }^{\circ} \mathrm{C}$, respectively, hence an increase in air temperature promotes a reduction in the drying time of fruits (Figure 1).

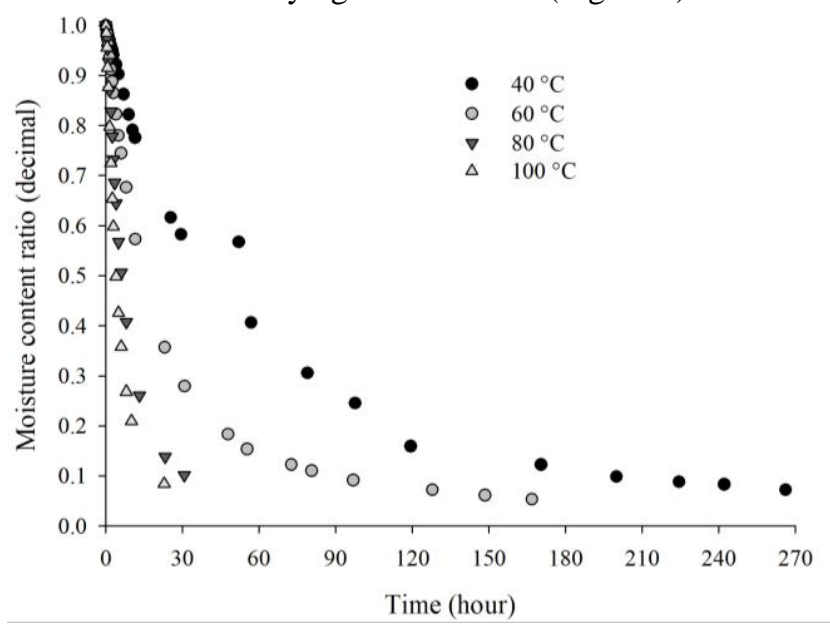

FIGURE 1. Moisture content ratio of baru fruits (D. alata Vogel) over drying time at temperatures of 40,60, 80, and $100{ }^{\circ} \mathrm{C}$.

The value of moisture content ratio decreased abruptly as drying temperature increased (Figure 1). In addition, as drying air temperature increased, a higher product water removal rate was observed, as reported in several studies for different plant products (Ferreira et al., 2012; Santos et al., 2013; Baptestini et al., 2016; Costa et al., 2016; Galdino et al., 2016).

Table 2 shows the values of the chi-square test and estimated mean error (SE) obtained for the different models fitted to the drying curves of baru fruits. All analyzed models presented adequate chi-square values. In general, the Thompson, Page, Midilli, logarithmic, two terms, and diffusion approximation models presented the lowest Chi-square values. Regarding SE, all models presented reduced values, being adequate for a good fit of models to the experimental data. 
TABLE 2. Values for the tests chi-square $\left(\chi^{2}\right.$, decimal $\left.\times 10^{-4}\right)$ and estimated mean error (SE, decimal) calculated for models used to represent the drying kinetics of baru (D. alata Vogel) fruits.

\begin{tabular}{|c|c|c|c|c|c|c|c|c|}
\hline \multirow{2}{*}{ Model } & \multicolumn{2}{|c|}{$40^{\circ} \mathrm{C}$} & \multicolumn{2}{|c|}{$60^{\circ} \mathrm{C}$} & \multicolumn{2}{|c|}{$80^{\circ} \mathrm{C}$} & \multicolumn{2}{|c|}{$100^{\circ} \mathrm{C}$} \\
\hline & $\chi^{2}$ & $\mathrm{SE}$ & $\chi^{2}$ & SE & $\chi^{2}$ & SE & $\chi^{2}$ & SE \\
\hline Wang and Sing & 46.4 & 0.068 & 145.4 & 0.121 & 19.4 & 0.044 & 18.3 & 0.043 \\
\hline Verma & 20.0 & 0.045 & 19.0 & 0.044 & 4.0 & 0.020 & 4.3 & 0.021 \\
\hline Thompson & 8.9 & 0.030 & 3.2 & 0.018 & 5.8 & 0.024 & 6.5 & 0.025 \\
\hline Page & 8.7 & 0.029 & 8.4 & 0.029 & 7.7 & 0.028 & 6.6 & 0.026 \\
\hline Newton & 18.5 & 0.043 & 17.4 & 0.042 & 7.4 & 0.027 & 6.4 & 0.025 \\
\hline Midilli & 8.7 & 0.030 & 2.0 & 0.014 & 1.4 & 0.012 & 1.7 & 0.013 \\
\hline Logarithmic & 10.7 & 0.033 & 1.9 & 0.014 & 1.5 & 0.012 & 1.8 & 0.013 \\
\hline Henderson and Pabis & 15.7 & 0.040 & 16.8 & 0.041 & 7.1 & 0.027 & 5.3 & 0.023 \\
\hline Exponential of two terms & 9.1 & 0.030 & 7.6 & 0.027 & 5.7 & 0.024 & 6.4 & 0.025 \\
\hline Two terms & 9.2 & 0.030 & 0.1 & 0.003 & 1.6 & 0.013 & 1.9 & 0.014 \\
\hline Diffusion approximation & 8.9 & 0.030 & 0.3 & 0.005 & 4.0 & 0.020 & 4.3 & 0.021 \\
\hline
\end{tabular}

Table 3 shows the coefficients of determination $\left(\mathrm{R}^{2}\right)$ and relative mean error $(\mathrm{P})$ for comparison between the analyzed models. Mathematical models presented high coefficients of determination, except the model Wang and Singh. Models with high coefficients of determination indicate a satisfactory representation for the drying process. The models with the highest coefficients of determination were Thompson, Page, Midilli, logarithmic, exponential of two terms, two terms, and diffusion approximation, regardless of the temperature.

Only the models Thompson, Midilli, logarithmic, two terms, and diffusion approximation presented relative mean error $(\mathrm{P})$ values for all temperatures below $10 \%$. In this sense, according to Mohapatra \& Rao (2005), for the models to represent the drying phenomenon properly, a relative mean error below $10 \%$ is necessary. Thus, these models are the most suitable to represent the drying of baru fruits.

TABLE 3. Coefficients of determination $\left(\mathrm{R}^{2}, \%\right)$ and relative mean error $(\mathrm{P}, \%)$ for the analyzed models during drying of baru fruits (D. alata Vogel) under different drying temperature conditions $\left({ }^{\circ} \mathrm{C}\right)$.

\begin{tabular}{|c|c|c|c|c|c|c|c|c|}
\hline \multirow{2}{*}{ Model } & \multicolumn{2}{|c|}{$40^{\circ} \mathrm{C}$} & \multicolumn{2}{|c|}{$60^{\circ} \mathrm{C}$} & \multicolumn{2}{|c|}{$80^{\circ} \mathrm{C}$} & \multicolumn{2}{|c|}{$100^{\circ} \mathrm{C}$} \\
\hline & $\mathrm{P}$ & $\mathrm{R}^{2}$ & $\mathrm{P}$ & $\mathrm{R}^{2}$ & $\mathrm{P}$ & $\mathrm{R}^{2}$ & $\mathrm{P}$ & $\mathrm{R}^{2}$ \\
\hline Wang and Sing & 20.466 & 96.53 & 49.06 & 90.33 & 12.29 & 97.94 & 8.90 & 98.15 \\
\hline Verma & 14.200 & 98.56 & 24.81 & 98.79 & 2.90 & 99.60 & 2.44 & 99.60 \\
\hline Thompson & 4.090 & 99.34 & 9.93 & 99.78 & 5.24 & 99.39 & 6.43 & 99.35 \\
\hline Page & 6.829 & 99.35 & 15.78 & 99.44 & 7.27 & 99.18 & 7.84 & 99.33 \\
\hline Newton & 14.200 & 98.56 & 24.81 & 98.79 & 7.89 & 99.16 & 7.39 & 99.31 \\
\hline Midilli & 3.918 & 99.40 & 6.23 & 99.88 & 2.58 & 99.87 & 2.25 & 99.86 \\
\hline Logarithmic & 3.737 & 99.23 & 7.49 & 99.88 & 1.58 & 99.85 & 1.53 & 99.83 \\
\hline Henderson and Pabis & 13.170 & 98.82 & 23.96 & 98.88 & 8.10 & 99.25 & 7.43 & 99.46 \\
\hline Exponential of two terms & 9.308 & 99.32 & 17.15 & 99.50 & 5.39 & 99.39 & 6.35 & 99.36 \\
\hline Two terms & 8.054 & 99.37 & 0.86 & 99.99 & 1.83 & 99.85 & 1.54 & 99.84 \\
\hline Diffusion approximation & 7.951 & 99.36 & 0.79 & 99.98 & 2.89 & 99.60 & 2.44 & 99.60 \\
\hline
\end{tabular}

Table 4 shows the values of the parameters of the models Thompson, Midilli, logarithmic, two terms, and diffusion approximation fitted to the experimental data of drying kinetics of baru fruits at different temperatures. These models presented estimated mean error values below $10 \%$, being the most adequate to represent the drying process of baru fruits.

Only the logarithmic model presented all parameters with significant values by the t-test. Thus, the logarithmic model was selected to represent the drying phenomenon of baru fruits. In addition, the magnitudes of the drying constant $k$ and the parameter $a$ increased as the drying air temperature increased (Table 4). On the other hand, the parameter $\mathrm{c}$ did not show a clear trend with an increased temperature. 
TABLE 4. Parameters of the models Thompson, Midilli, logarithmic, two terms, and diffusion approximation fitted for different drying conditions of baru (D. alata Vogel) fruits.

\begin{tabular}{|c|c|c|c|c|}
\hline \multirow{2}{*}{ Parameter } & \multicolumn{4}{|c|}{ Temperature $\left({ }^{\circ} \mathrm{C}\right)$} \\
\hline & 40 & 60 & 80 & 100 \\
\hline & \multicolumn{4}{|c|}{ Thompson } \\
\hline a & $-6.72844^{* *}$ & $-4.75078^{* *}$ & $-9.08335^{*}$ & $-13.6793^{\mathrm{ns}}$ \\
\hline \multirow[t]{2}{*}{$\mathrm{b}$} & $0.37770^{* *}$ & $0.51890^{* *}$ & $1.01066^{* *}$ & $1.5261^{*}$ \\
\hline & \multicolumn{4}{|c|}{ Midilli } \\
\hline $\mathrm{a}$ & $1.007300^{* *}$ & $1.024445^{* *}$ & $1.020260^{* *}$ & $1.022305^{* *}$ \\
\hline $\mathrm{k}$ & $0.030846^{* *}$ & $0.071452^{* *}$ & $0.109998^{* *}$ & $0.171084^{* *}$ \\
\hline $\mathrm{n}$ & $0.833390^{* *}$ & $0.844882^{* *}$ & $1.045745^{* *}$ & $1.038561^{* *}$ \\
\hline \multirow[t]{2}{*}{$\mathrm{b}$} & $0.000103^{\mathrm{ns}}$ & $0.000421^{* *}$ & $0.003104^{* *}$ & $0.003414^{* *}$ \\
\hline & \multicolumn{4}{|c|}{ Logarithmic } \\
\hline $\mathrm{a}$ & $0.911724^{* *}$ & $0.917230^{* *}$ & $0.944254^{* *}$ & $0.962794^{* *}$ \\
\hline $\mathrm{k}$ & $0.017255^{* *}$ & $0.051663^{* *}$ & $0.130410^{* *}$ & $0.197454^{* *}$ \\
\hline \multirow[t]{2}{*}{$\mathrm{c}$} & $0.070180^{* *}$ & $0.082451^{* *}$ & $0.086418^{* *}$ & $0.070809^{* *}$ \\
\hline & \multicolumn{4}{|c|}{ Two terms } \\
\hline $\mathrm{a}$ & $0.820626^{* *}$ & $0.796116^{* *}$ & $0.061104^{\mathrm{ns}}$ & $0.037974^{\mathrm{ns}}$ \\
\hline $\mathrm{k}_{0}$ & $0.011334^{* *}$ & $0.063355^{* *}$ & $-0.011338^{\mathrm{ns}}$ & $-0.027937^{\mathrm{ns}}$ \\
\hline $\mathrm{b}$ & $0.186481^{* *}$ & $0.211949^{* *}$ & $0.968744^{* *}$ & $0.993755^{* *}$ \\
\hline \multirow[t]{2}{*}{$\mathrm{k}_{1}$} & $0.092732^{*}$ & $0.008508^{* *}$ & $0.126721^{* *}$ & $0.189091^{* *}$ \\
\hline & \multicolumn{4}{|c|}{ Diffusion approximation } \\
\hline $\mathrm{a}$ & $0.188057^{*}$ & $0.805022^{* *}$ & $0.987270^{* *}$ & $0.99904^{* *}$ \\
\hline $\mathrm{k}$ & $0.081676^{*}$ & $0.060455^{* *}$ & $0.110474^{* *}$ & $0.16608^{* *}$ \\
\hline $\mathrm{b}$ & $0.137565^{* *}$ & $0.129341^{* *}$ & $-0.518596^{\mathrm{ns}}$ & $-1.09801^{\mathrm{ns}}$ \\
\hline
\end{tabular}

**Significant at $1 \%$ by the t-test; *Significant at $5 \%$ by the $\mathrm{t}$-test. ${ }^{\text {ns }}$ Non-significant by the t-test.

Figure 2 shows the drying curves of baru fruits, estimated by the logarithmic model. A satisfactory fit of the model to the experimental values obtained during drying of baru fruits can be observed.

Chen et al. (2015) studied the drying of Zizyphus jujuba Mill. at temperatures of $60,70,80$, and $90{ }^{\circ} \mathrm{C}$; in their study, the models logarithmic and two terms were the best fit to the experimental data. On the other hand, Costa et al. (2015) studied the drying of crambe fruits (Crambe abyssinica) at temperatures of $35,45,60,75$, and $90{ }^{\circ} \mathrm{C}$ and found Page model as the best fit.

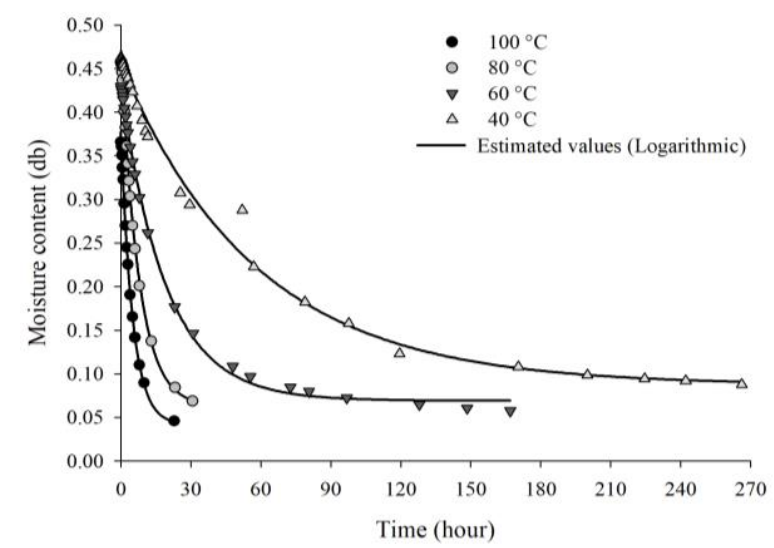

FIGURE 2. Values of experimental moisture content and predicted by the Logarithmic model for drying of baru fruits (D. alata Vogel) under different temperature conditions.

The effective diffusion coefficient of baru fruits increased linearly as drying air temperature increased and its dependence was represented by the Ahrrenius expression (Figures 3A and 3B), in accordance with the results found in other studies on coffee (Isquierdo et al.,
2013), crambe fruits (Costa et al., 2015), and grains of bonnet pepper (Rodovalho et al., 2015).

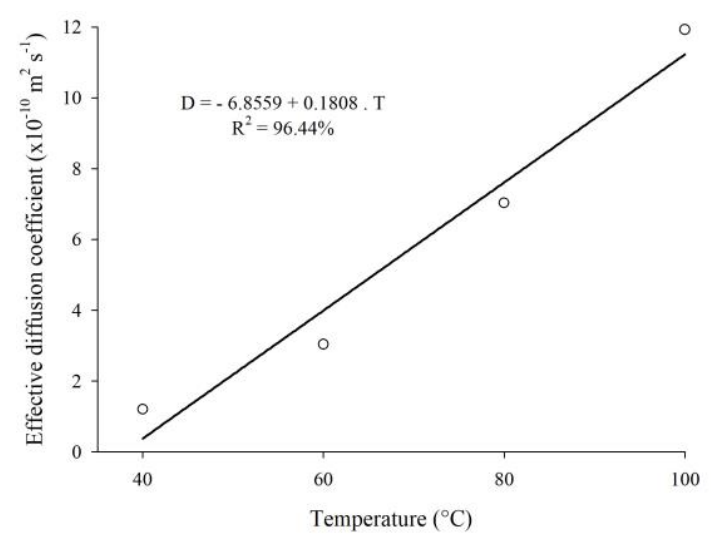

(A)

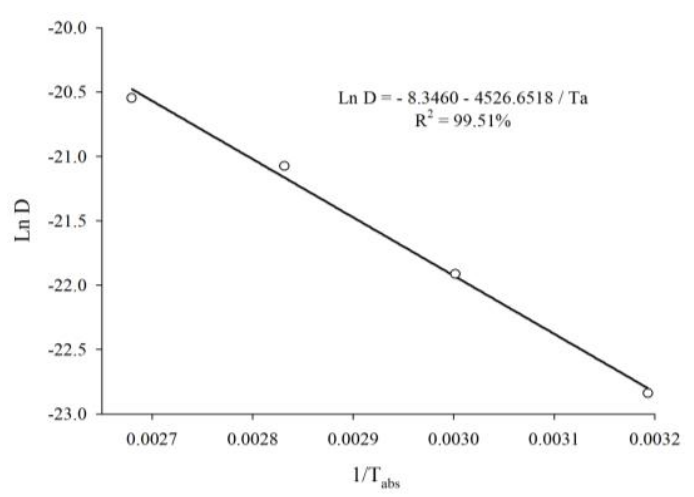

(B)

FIGURE 3. Effective diffusion coefficient (A) and Arrhenius representation for the effective diffusion coefficient (B) obtained for drying of baru fruits (D. alata Vogel) at temperatures of $40,60,80$, and $100{ }^{\circ} \mathrm{C}$. 
Water diffusivity depends on drying air temperature, i.e. the higher the drying air temperature is the lower the fruit resistance to water removal, increasing diffusivity. Effective diffusion coefficients of baru fruits showed magnitudes between $1.20 \times 10^{-10}$ to $11.93 \times 10^{-10}$ $\mathrm{m}^{2} \mathrm{~s}^{-1}$. Costa et al. (2015) found similar values for crambe fruits, with values of $2.84 \times 10^{-10}$ and $9.14 \times 10^{-11} \mathrm{~m}^{2} \mathrm{~s}^{-1}$ for temperatures of 35 and $90{ }^{\circ} \mathrm{C}$, respectively. The activation energy for the drying phenomenon of baru fruits was $37.64 \mathrm{~kJ} \mathrm{~mol}^{-1}$ for the studied temperature range.

Table 5 shows that as drying temperature increased, enthalpy and entropy decreased, while Gibbs free energy increased. Enthalpy is related to the energy required to remove the water bound to the dry matter during the drying process. Thus, enthalpy is reduced as drying temperature decreased. The lowest enthalpy value at lower temperatures means a higher amount of energy required to promote the drying of baru fruits. The enthalpy behavior for baru fruits is similar to the findings obtained by Rodovalho et al. (2015) and Costa et al. (2016) for bonnet pepper grains and jabuticaba bark, respectively.

TABLE 5. Values of enthalpy $\left(\mathrm{H}, \mathrm{J} \mathrm{mol}^{-1}\right)$, entropy $\left(\mathrm{S}, \mathrm{J} \mathrm{mol}^{-1} \mathrm{~K}^{-1}\right)$, and Gibbs free energy $\left(\mathrm{G}, \mathrm{J} \mathrm{mol}^{-1}\right)$ for different conditions of drying air of baru fruits (D. alata Vogel).

\begin{tabular}{cccc}
\hline \multirow{2}{*}{ Temperature $\left({ }^{\circ} \mathrm{C}\right)$} & \multicolumn{3}{c}{ Thermodynamic properties } \\
\cline { 2 - 4 } & $\mathrm{H}$ & $\mathrm{S}$ & $\mathrm{G}$ \\
\hline 40 & 35031.45 & -175.93 & 90122.65 \\
60 & 34865.17 & -176.44 & 93646.37 \\
80 & 34698.89 & -176.93 & 97180.08 \\
100 & 34532.61 & -177.38 & 100723.21 \\
Equation & $\mathrm{H}=35364.01-8.31 \mathrm{~T}$ & $\mathrm{~S}=-174.97-0.024 \mathrm{~T}$ & $\mathrm{G}=83050.7+176.7 \mathrm{~T}$ \\
$\mathrm{R}^{2}(\%)$ & 99.99 & 99.93 & 99.99 \\
\hline
\end{tabular}

Entropy decreased as drying air temperature increased, a similar behavior to the drying of other products such as seeds of Vigna subterranea (L.) Verdc. (Jideani \& Mpotokwana, 2009) and 'Cabacinha' pepper fruits (Silva et al., 2016).

Gibbs free energy was positive and increased as drying temperature increased. Gibbs free energy is related to the work required to make the sorption sites available, and its positive value indicates an endergonic reaction, in which the addition of energy to the air is necessary for drying of the product (Nkolo Meze'e et al., 2008). Silva et al. (2014), Rodovalho et al. (2015), and Silva et al. (2016) also reported this behavior.

\section{CONCLUSIONS}

Drying time decreases as temperature increases, with a value of 266.3 hours for a temperature of $40{ }^{\circ} \mathrm{C}$ and 22.8 hours for a temperature of $100^{\circ} \mathrm{C}$.

The models of Thompson, Midilli, logarithmic, two terms, and diffusion approximation are adequate to represent the drying of baru fruits, with the logarithmic model selected to represent the drying phenomenon.

The effective diffusion coefficient increases as temperature increases, being described by the Arrhenius equation, with an activation energy of $37.64 \mathrm{~kJ} \mathrm{~mol}^{-1}$.

Enthalpy and entropy decrease, while the Gibbs free energy increases as drying temperature increases.

\section{REFERENCES}

Baptestini FM, Corrêa PC, Oliveira GHH, Almeida LFJ, Vargas-Elías GA (2016) Constant and decreasing periods of pineapple slices dried by infrared. Revista Brasileira de Ciências Agrárias 11(1):53-59. Available:

http://www.agraria.pro.br/ojs-

2.4.6/index.php?journal=agraria $\&$ page $=$ article $\& o p=v i e w \&$ path\%5B\%5D=agraria_v11i1a5160. Accessed: Jun 21, 2016.
Brasil (2009) Ministério da Agricultura e Reforma Agrária. Secretaria Nacional de defesa Agropecuária. Regras para Análise de Sementes. 395p. Available: http://www.agricultura.gov.br/arq_editor/file/2946_regras_ analise_sementes.pdf. Accessed: Apr 6, 2016.

Chen Q, Bi J, Wu X, Yi J, Zhou L, Zhou Y (2015) Drying kinetics and quality attributes of jujube (Zizyphus jujuba Miller) slices dried by hot-air and short- and medium-wave infrared radiation. LWT - Food Science and Technology 64(2):759-766. Available:

http://www.sciencedirect.com/science/article/pii/S0023643 815300141. Accessed: Apr 6, 2016.

Correa GC, Naves RV, Rocha MR, Chaves LJ, Borges JD (2008) Determinações físicas em frutos e sementes de baru (Dipteryx alata Vog.), cajuzinho (Anacardium othonianum Rizz.) e pequi (Caryocar brasiliense Camb.), visando melhoramento genético. Bioscience Journal 24(4):42-47. Available:

http://www.seer.ufu.br/index.php/biosciencejournal/article/ viewFile/6628/4356. Accessed: Apr 6, 2016.

Costa LM, Resende O, Gonçalves DN, Oliveira DEC (2015) Modelagem matemática da secagem de frutos de crambe em camada delgada. Bioscience Journal 31(2):392403. Available:

http://www.seer.ufu.br/index.php/biosciencejournal/article/ view/22340/16114. Accessed: Apr 6, 2016.

Costa CF, Corrêa PC, Vanegas JDB, Baptestini FM, Campos RC, Fernandes LS (2016) Mathematical modeling and determination of thermodynamic properties of jabuticaba peel during the drying process. Revista Brasileira de Engenharia Agrícola e Ambiental 20(6):576580. Available: http://www.scielo.br/pdf/rbeaa/v20n6/1415-4366-rbeaa20-06-0576.pdf. Accessed: Jun 21, 2016. 
Ferreira LFD, Pirozi MR, Ramos AM, Perreira JAM (2012) Modelagem matemática da secagem em camada delgada de bagaço de uva fermentado. Pesquisa Agropecuária Brasileira 47(6):855-862. Available: https://seer.sct.embrapa.br/index.php/pab/article/view/109 86. Accessed: Jun 21, 2016.

Galdino PO, Figueirêdo RMF, Queiroz AJM, Galdino PO (2016) Drying kinetics of atemoya pulp. Revista Brasileira de Engenharia Agrícola e Ambiental 20(7):672-677. Available:

<http://www.agriambi.com.br/revista/v20n07/v20n07a14.p df $>$. Accessed: Jun 21, 2016.

Isquierdo EP, Borém FM, Andrade ET, Corrêa JLG, Oliveira PD, Alves GE (2013) Drying kinetics and quality of natural coffee. Journal of Food Engineering 56(3):10031010. Available:

http://elibrary.asabe.org/abstract.asp?aid=42732\&t=2\&redi $\mathrm{r}=\&$ redirType $=$. Accessed: Apr 6, 2016.

Jideani VA, Mpotokwana SM (2009) Modeling of water absorption of botswana bambara varieties using Peleg's equation. Journal of Food Engineering 92(2):182-188. Available:

http://www.sciencedirect.com/science/article/pii/S0260877 408005384. Accessed: Apr 6, 2016.

Mohapatra D, Rao PS (2005) A thin layer drying model of parboiled wheat. Journal of Food Engineering 66(4):513518. Available: http://www.sciencedirect.com/science/article/pii/S0260877 404001888. Accessed: Apr 6, 2016.

Nkolo Meze'e YN, Noah Ngamveng J, Bardet S (2008) Effect of enthalpy-entropy compensation during sorption of water vapour in tropical woods: The case of Bubinga (Guibourtia Tessmanii J. L'eonard; G. Pellegriniana J.L.). Thermochimica Acta 468(3-4):1-5. Available: http://www.sciencedirect.com/science/article/pii/S0040603 10700425X. Accessed: Apr 6, 2016.
Rodovalho RS, Silva HW, Silva IL, Rossetto CAV (2015) Cinética de secagem dos grãos de pimenta bode. Global Science Technology 8(2):128-142. Available: http://rv.ifgoiano.edu.br/periodicos/index.php/gst/article/vi ew/715/471. Accessed: Apr 6, 2016.

Santos DC, Queiroz AJM, Figueirêdo RMF, Oliveira ENA (2013) Cinética de secagem de farinha de grãos residuais de urucum. Revista Brasileira de Engenharia Agrícola e Ambiental 17(2):223-231. Available: http://www.scielo.br/pdf/rbeaa/v17n2/v17n02a14.pdf. Accessed: Apr 6, 2016.

Silva LA, Resende O, Virgolino ZZ, Bessa JFV, Morais WA, Vidal VM (2015) Cinética de secagem e difusividade efetiva em folhas de jenipapo (Genipa americana L.). Revista Brasileira de Plantas Medicinais 17(4):953-963. Available: http://www.scielo.br/pdf/rbpm/v17n4s2/15160572-rbpm-17-4-s2-0953.pdf. Accessed: Apr 6, 2016.

Silva RM, Placido GR, Oliveira DEC, Silva MAP, Caliari M (2014) Pequi pulp (Caryocar brasiliense Cambess): drying kinetics and thermodynamic properties. African Journal of Biotechonology 13(33):3443-3449. Available: http://www.academicjournals.org/journal/AJB/articleabstract/61E3A8C46628. Accessed: Jun 21, 2016.

Silva HW, Rodovalho RS, Velasco MF, Silva CF, Vale LSR (2016) Kinetics and thermodynamic properties related to the drying of 'Cabacinha' pepper fruits. Revista Brasileira de Engenharia Agrícola e Ambiental 20(2):174180. Available:

http://www.scielo.br/scielo.php?script=sci_arttext\&pid=S1 415-43662016000200174. Accessed: Apr 6, 2016. 